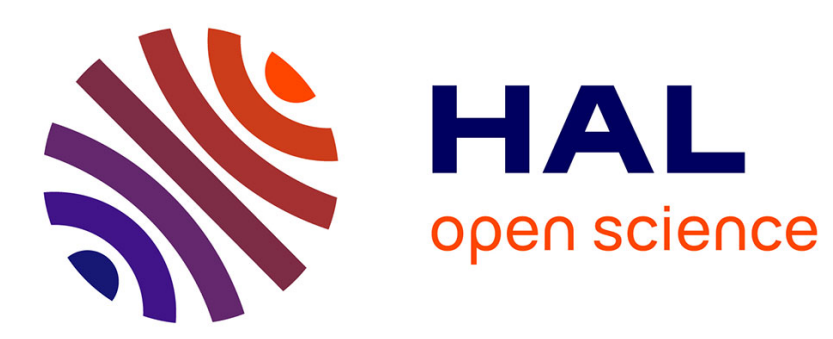

\title{
Crystal and Electronic Structures and the Corrosion Resistance for Metal Nitrides in the TiN-AIN System
}

\author{
M. Takahashi, F. Kanamaru, M. Harada, I. Watanabe
}

\section{To cite this version:}

M. Takahashi, F. Kanamaru, M. Harada, I. Watanabe. Crystal and Electronic Structures and the Corrosion Resistance for Metal Nitrides in the TiN-AIN System. Journal de Physique IV Proceedings, 1997, 7 (C2), pp.C2-1215-C2-1216. 10.1051/jp4:19972200 . jpa-00255272

\section{HAL Id: jpa-00255272 https://hal.science/jpa-00255272}

Submitted on 1 Jan 1997

HAL is a multi-disciplinary open access archive for the deposit and dissemination of scientific research documents, whether they are published or not. The documents may come from teaching and research institutions in France or abroad, or from public or private research centers.
L'archive ouverte pluridisciplinaire HAL, est destinée au dépôt et à la diffusion de documents scientifiques de niveau recherche, publiés ou non, émanant des établissements d'enseignement et de recherche français ou étrangers, des laboratoires publics ou privés. 


\title{
Crystal and Electronic Structures and the Corrosion Resistance for Metal Nitrides in the TiN-AIN System
}

\author{
M. Takahashi, F. Kanamaru, M. Harada and I. Watanabe \\ ISIR, Osaka University, 8-1 Mihogaoka, Ibaraki, Osaka 567, Japan \\ * Department of Chemistry, Faculty of Science, Osaka University, Toyonaka, Osaka 560, Japan
}

\begin{abstract}
Both aluminum and titanium $K$-edge XAFS spectra of $\mathrm{Ti}_{1-x} \mathrm{Al}_{\mathrm{x}} \mathrm{N}(0 \leq \mathrm{x} \leq 1.0)$ films were measured to investigate the corrosion resistance of compounds in the TiN-AIN system. Analyses of both Al and Ti $K$-XAFS revealed that both $\mathrm{Ti}$ and $\mathrm{Al}$ atoms occupy the octahedral site in the $\mathrm{NaCl}-$ type $\mathrm{Ti}_{1-\mathrm{x}} \mathrm{Al}_{\mathrm{x}} \mathrm{N}(0 \leq \mathrm{x} \leq 0.58)$ and the tetrahedral site in both the würtzite-type $\mathrm{Ti}_{1-\mathrm{x}} \mathrm{Al}_{\mathrm{x}} \mathrm{N}$ $(0.83 \leq x \leq 1.0)$ and the intermediate phase $(x \approx 0.7)$. Ti $K$-XAFS of $T_{1-x} A l_{x} N$ films annealed in $O_{2}$ gas flow and aged in distilled water were also measured by employing the helium ion yield technique with a small angle incidence. The XANES spectrum of annealed TiN film shows the pre-edge feature, which is observed for rutile phase $\mathrm{TiO}_{2}$ and such feature is not appreciably observed for $\mathrm{NaCl}$-type $\mathrm{Ti}_{1-\mathrm{x}} \mathrm{Al}_{2} \mathrm{~N}$ 's and merely observed for the intermediate phase and würtzite-type $\mathrm{Ti}_{1-\mathrm{x}} \mathrm{Al} \times \mathrm{N}$ 's. It has been found from the XANES spectra that $T_{1-x} A_{x} N(x=0.9)$ is oxidized in water and $\mathrm{Al}_{2} \mathrm{TiO}_{5}$ is produced while $\mathrm{TiN}_{\mathrm{N}}$ and $\mathrm{Ti}_{1-\mathrm{x}} \mathrm{Al} \mathrm{N}_{\mathrm{N}} \mathrm{N}$ $(x \leq 0,8)$ is hardly oxidized. Resuits of the XPS measurements and the DV-X $a$ MO calculations are also discussed.
\end{abstract}

\section{INTRODUCTION}

TiN has been used for hard coatings for machining operations, diffusion barrier layers for electronic device fabrications, and so on. In order to improve properties of TiN coatings, the addition of other metal to TiN has been examined by many researchers and it has been found that $\mathrm{Ti}_{1-x} \mathrm{Al}_{\mathrm{x}} \mathrm{N}$ fi]ms is not oxidized below $900^{\circ} \mathrm{C}$ in air[1] and seem to provide a promising alternative to $\operatorname{TiN}$ films[2]. Such high oxidation resistance of $\mathrm{Ti}_{1-x} \mathrm{Al}_{\mathrm{x}} \mathrm{N}$ has been thought to be due to the formation of a bilayer oxide composed of two sublayers[3]. Owing to the small sample volume and the highly defective nature of the oxide layers, however, there was too few crystallographic information on the layers. In the present work the He ion yield XAFS technique[4] with a small incidence angle is used to allow Ti $K$-XAFS measurements to be sensitive to the surface layer. The technique is applied to the local structure investigation on the oxidized layer of $T_{i_{1-x}} \mathrm{Al}_{\mathrm{x}} \mathrm{N}$ films. Ti $K-$ and $A \mathrm{I} K-\mathrm{XAFS}$ were also measured for as-deposited films to obtain information on the local structure around both Ti and Al for the solid solutions.

\section{EXPERIMENTAL}

$\mathrm{Ti}_{1-\mathrm{x}} \mathrm{Al}_{\mathrm{x}} \mathrm{N}$ films were prepared using the $\mathrm{rf}$-magnetron sputtering apparatus under the mixed gas atmosphere, comprising Ar and $\mathrm{N}_{2}$. Metal composites formed by $\mathrm{Al}$ tips on Ti disk or Ti tips on $\mathrm{Al}$ disk were used as the target. Films were grown onto a polycrystalline alumina substrate and a polystyrene film, coated on a glass slide for $T ; K-X A F S$ and Al $K-X A F S$ measurements, respectively. The polystyrene substrate deposited films was sunk in THF to separate product film from the glass slide and the film was washed three times by THF to remove polystyrene. Annealing of deposited films was carried out in flowing pure $\mathrm{O}_{2}$ for $10 \mathrm{~min}$. Each one piece of as-deposited films was dipped into distilled water for 2 weeks. As-deposited and oxidized films and films peeled off from a glass slide were stored in $n$-hexane to prevent surface oxidation.

AI $K$-edge XAFS spectra were measured at the BL-7A in UVSOR of Institute for Molecular Science in Okazaki with $750 \mathrm{MeV}$ electrons. The two-crystal monochromator of a beryl was used and the photon energy was calibrated using Al metal powder. The sample, mixed with active carbon in $n$-hexane, were applied on the first dinode of the electron multiplier. $I_{0}$ was monitored by the gold mesh transmitting $80 \%$ of photons and the total electron yield was recorded. The conversion electron yield method under atmospheric He gas flow[4] was used to measure Ti $K-X A F S$ of the films at $B L-12 C$ in the Photon Factory of the National Laboratory for High Energy Physics in Tsukuba, with $2.5 \mathrm{GeV}$ electrons. The incident $\mathrm{X}$-ray was monochromatized with $\mathrm{Si}(111)$ double crystals and focused by the mirror, and the higher harmonics were rejected using a quarts mirror in He gas flowing. An incidence angle of the sample was varied by the computer-controlled precision stage. The experimental setup for the He ion yield XAFS measurements has been described elsewhere[4].

\section{RESULTS and DISCUSSION}

Figure 1 shows the normalized $\mathrm{Ti} K$-XAFS spectra of $\mathrm{Ti}_{1-\mathrm{x}} \mathrm{Al}_{\mathrm{x}} \mathrm{N}$ films before and after annealed in flowing $\mathrm{O}_{2}$. The dashed line depicts as-deposited films. Spectra of $\mathrm{Ti}_{1-x} \mathrm{Al}_{\mathrm{x}} \mathrm{N}(\mathrm{x} \leq 0.3)$ have small pre-edge peak and rather intense white line, while those with $x \geq 0.7$ shows intense pre-edge peak, indicating that $\mathrm{Ti}$ is tetrahedrally coordinated by four $\mathrm{N}_{\text {atoms }}$ in $\mathrm{Ti}_{1-\mathrm{x}} \mathrm{Al} \mathrm{x}_{\mathrm{x}} \mathrm{N}$ $(x \geq 0.7)$. On the other hand, $T i-r i c h T_{1-x} A_{x} N$ 's take the same coordination state for $T i$ as that in $T i N$, ie., $T i$ is octahedrally coordinated by six $\mathrm{N}$ atoms. These coincide with findings by the XRD measurements that $\mathrm{Ti}_{1-\mathrm{x}} \mathrm{Al}_{\mathrm{x}} \mathrm{N}$ crystallizes in three crystal phases with $\mathrm{Al}$ content, $\mathrm{x}$, ie., $\mathrm{NaCl}$-type solid solution with $0<\mathrm{x} \leq 0.58$, würtzite-type solid solution with $0.83 \leq \mathrm{x}<0$ and a intermediate phase belonging to the hexagonal system in the vicinity of $\mathrm{x}=0.7$. In the $\mathrm{Al} K$-edge XANES spectrum for AlN 
a sharp absorption peak is found at $1.5628 \mathrm{keV}$ and another peak is located at $1.5687 \mathrm{keV}$. The spectral shape for $\mathrm{Ti}_{1-\mathrm{x}} \mathrm{Al}_{\mathrm{x}} \mathrm{N}$ $(\mathrm{x}=0.8)$ closely resembles that for AIN. The position of the peak around $1.563 \mathrm{keV}$ slightly shifts to higher energy side and becomes weaker and broader for $\mathrm{Ti}_{I_{-x}} \mathrm{Al}_{\mathrm{x}} \mathrm{N}(\mathrm{x}=0.7)$. Thus the local structure around $\mathrm{Al}$ in the würtzite-type solid solution resembles to that for $\mathrm{AIN}$, ie., $\mathrm{Al}$ occupies the tetrahedral site, and as for $\operatorname{Ti}_{1-5} A l_{x} N(x \approx 0.7)$ the coordination and the electronic states for $\mathrm{Al}$ somewhat differ from those for $\mathrm{AlN}$, though the phase takes the structure which resembles to the wuirtzite-type one. The XANES spectra for the $\mathrm{NaCl}$-type solid solutions are completely different from that for AlN, suggesting that $\mathrm{Al}$ no more occupies the tetrahedral site. The position of the pre-edge peak at both Ti and Al $K$-XANES shifts to lower energy side with increasing Al content, corresponds to the findings, obtained by XPS measurements, that the highest occupied leveI shifts to higher binding energy side with an increment of $\mathrm{Al}$.

An oxidation at $600^{\circ} \mathrm{C}$ under $\mathrm{O}_{2}$ gas flow makes TiN into rutile phase $\mathrm{TiO}_{2}$ as shown in Figs.1(a) and (b). The intensity of the pre-edge peak around $4.968 \mathrm{keV}$ for $\mathrm{NaCl}$-type $\mathrm{Ti}_{1-\mathrm{x}} \mathrm{Al}_{\mathrm{x}} \mathrm{N}$ increases with the oxidation at $600^{\circ} \mathrm{C}$ and so does for TiN oxidized at $400^{\circ} \mathrm{C}$. In addition the intensity around $4.99 \mathrm{keV}$, where the dip is observed for spectra of as-deposited films, increases after the annealing at $600^{\circ} \mathrm{C}$. These findings indicate that the oxidation causes a partial oxidization of the film surface and the product oxide is $\mathrm{TiO}_{2}$-like species. $\mathrm{Ti}_{1-\mathrm{x}} \mathrm{Al}_{\mathrm{x}} \mathrm{N}(\mathrm{x} \approx 0.7)$ is also oxidized partially at $600^{\circ} \mathrm{C}$, while würtzite-type $\mathrm{Ti}_{1-\mathrm{x}} \mathrm{Al}_{\mathrm{x}} \mathrm{N}$ 's hardly oxidized, though no oxidation has been defected for $\mathrm{Ti}_{1-\mathrm{x}} \mathrm{Al}_{\mathrm{x}} \mathrm{N}(0<\mathrm{x} \leq 1)$ by the TG analyses[1]. The fact

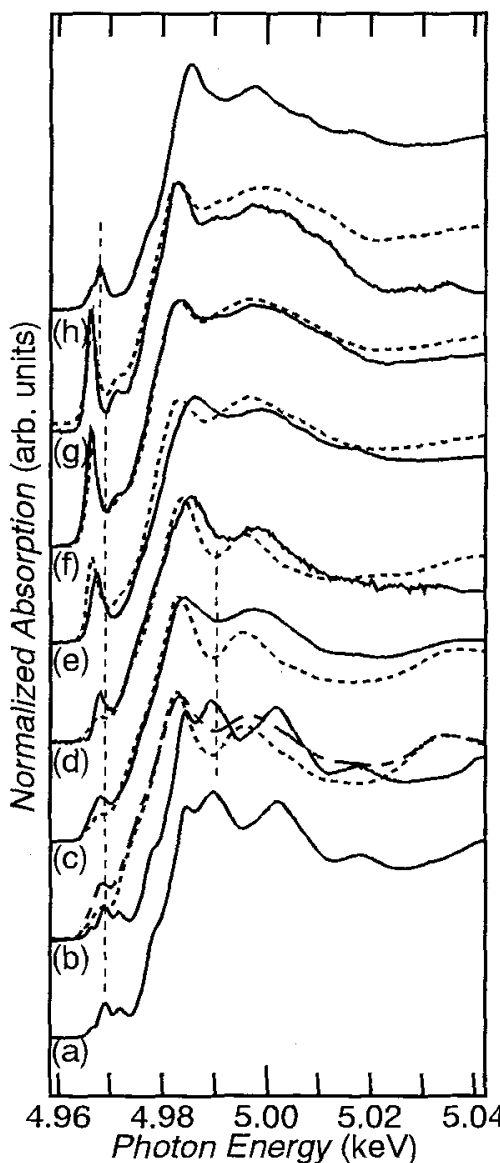

Fig. 1 Ti $K$-XAFS spectra for $\mathrm{Ti}_{1-\mathrm{x}} \mathrm{Al}$. $\mathrm{N}$ and $\mathrm{TiO}_{2}$ films and $\mathrm{Al}_{2} \mathrm{TiO}_{5}$ powder. (a) $\mathrm{TiO}_{2}$, (b) TiN, (c) $x=0.1, \quad$ (d) $x=0.3, \quad$ (e) $x=0.7$, (f) $\mathrm{x}=0.8$, (g) $\mathrm{x}=0.9$, and (h) $\mathrm{Al}_{2} \mathrm{TiO}_{5}$, Asdeposited films are plotted by a broken line. A solid line shows films annealed at $600^{\circ} \mathrm{C}$ and an alternative long and short dash line depicts TiN oxidized at $400^{\circ} \mathrm{C}$

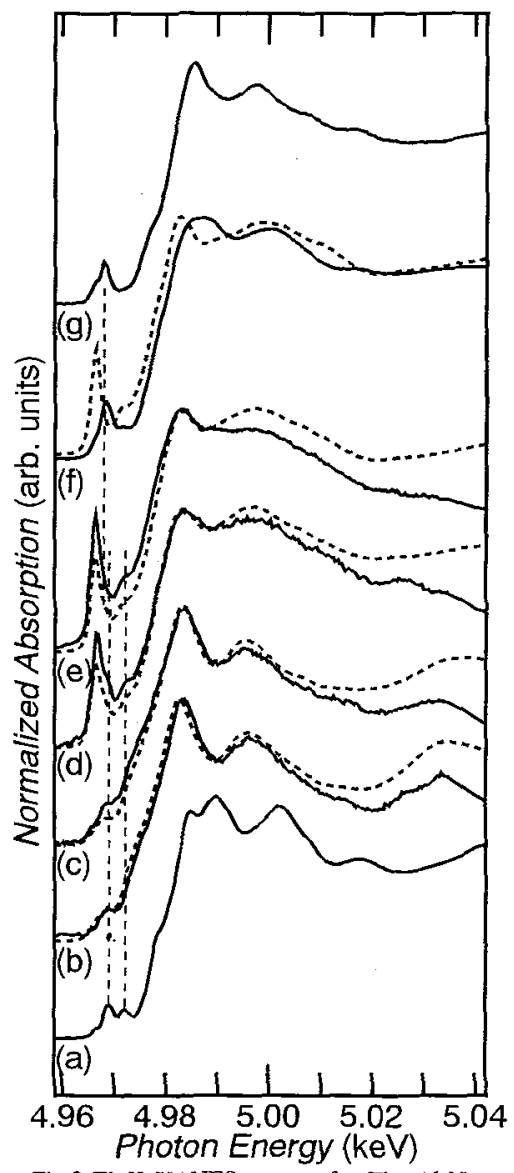

Fig. 2 Ti $K$-XANES spectra for $\mathrm{Ti}_{1-\mathrm{x}} \mathrm{Al}_{\mathrm{X}} \mathrm{N}$ and TiO films and $\mathrm{Al}_{2} \mathrm{TiO}_{5}$ powder. $\begin{array}{llll}\text { (a) } \mathrm{TiO}_{2}, & \text { (b) TiN, (c) } x=0.1, & \text { (d) } \mathrm{x}=0.7 \text {, }\end{array}$ (e) $x=0.8$, (f) $x=0.9$, and (g) $\mathrm{Al}_{2} \mathrm{TiO}_{5}$. A solid line indicates films soaked in distilled water for 2 weeks. As-deposited films are displayed by a broken line. that würtzite-type $\mathrm{Ti}_{1-x} \mathrm{Al}_{\mathrm{x}} \mathrm{N}$ 's are rarely oxidized seems to be caused by the large covalency, which results in the intense pre-edge peak. The DV-X $\alpha$ MO calculations for $\mathrm{TiN}$ and $\mathrm{NaCl}-$ type solid solutions implies that the increment of covalency of the metal-metal bond with the substitution of $\mathrm{Al}$ for $\mathrm{Ti}$ leads to the improvement of the durability against oxidation, which is consistent with the present XAFS measurements. Slightly thick surface oxide layer is found in XPS of these films as compared with those of corresponding asdeposited films, showing the present technique for the XAFS measurement is valid for the detection of the surface oxidation of the film.

By aging in distilled water, $\mathrm{Ti}_{1-\mathrm{x}} \mathrm{Al}_{\mathrm{x}} \mathrm{N} \quad(\mathrm{x}=0.9) \quad$ is almost changed to $\mathrm{Al}_{2} \mathrm{TiO}_{5}$, while both TiN and $\mathrm{NaCl}$-type $\mathrm{Ti}_{1-\mathrm{x}} \mathrm{Al}_{\mathrm{x}} \mathrm{N}$ is hardly oxidized, as shown in Fig. 2. An existence of a little amount of $\mathrm{TiO}_{2}$ is observed for $\mathrm{Ti}_{1-x} \mathrm{Al}_{x} \mathrm{~N}$ $(x \approx 0.7$ and $x=0.8)$. These findings suggest that the water resistance for AIN is improved with an addition of $T i$ but a considerable dose of $\mathrm{Ti}$ is required.

\section{Acknowledgements}

This work has been performed under the approval of the Photon Factory Program Advisory Committee (Proposal No. 95G220) and the Joint Studies Program $(7-843)$ of UVSOR, IMS.

\section{References}

[1] Inamura S., Takahashi M., Nobugai K., Kanamaru F. and Miyamoto D., J. Soc. Mater. Sci. Jpr. 37 (1988) 83.

[2] Jehn H.A., Hofmann S., Rückborn V.E. and Münz W.D., J. Vac. Sci Technol. A4 (1986) 2701; Münz W.D., ibid., A4 (1986) 2717; Randhawa H. Johnson P.C. and Cunnungham R., ibid., A6 (1988) 2173.

[3] Mclntyre D. Greene J.E. Hâkansson G. Sundgren J.-E. and Münz W.D., J. Appl. Phys., 67 (1990) 1542

[4] Takahashi M., Watanabe I., Harada M. and Kanamaru F., Physica B, 208\&209 (1995) 565. 